\title{
Cognitive Constructivist Way of Teaching Scientific and Technical Contents
}

\author{
Darjo Zuljan ${ }^{1 *}$, Milena Valenčič Zuljan², Petra Pejić Papak ${ }^{3}$
}

\author{
'University of Primorska, Faculty of Education, Slovenia, e-mail: darjo.zuljan@pef.upr.si \\ ${ }^{2}$ University of Ljubljana, Faculty of Education, Slovenia e-mail: milena.valencic-zuljan@guest.arnes.si \\ 3University of Rijeka, Faculty of Teacher Education Rijeka, Croatia, e-mail: petra.pejic.papak@uniri.hr
}

\begin{abstract}
For pupils to obtain high-quality and permanent knowledge, it is important that the teaching of scientific and technical contents is based on cognitive constructivist approach. We carried out a research, during which we asked three research questions, on a sample of 167 class teachers in the Republic of Slovenia. We wanted to find out: how often class teachers included elements typical of cognitive constructivist approach; was the frequency of using elements of cognitive constructivist teaching model linked to the teacher's concern for their own professional development, and was the frequency of using elements of cognitive constructivist teaching model linked to the factors, such as the teacher's estimated importance, difficulty and necessity of Science and Technics, the assessment of their own competence and professional enthusiasm. Data were collected with three scales: ways of teaching scientific and technical contents; attitude to scientific and technical contents and teaching and components of professional development. Data were processed according to descriptive and inferential statistics. The research showed that the formulation and verification of hypotheses, two important elements in view of cognitive constructivist teaching model, were less often represented. With statistically significant higher frequency they were organized by teachers, who rated their competence higher, were more enthusiastic and cared more about their professional development. Keywords: cognitive constructivist teaching model, science and technics, competence, professional enthusiasm, professional development.
\end{abstract}

\section{Introduction}

In today's highly developed technological world, in the time of fast and unpredictable technological changes, a relevant technological competence is of fundamental importance for people. Social and economic changes challenge expert consideration on the importance of technology and the ways of education that will, along the entire vertical of national school systems: from pre-school to post-graduate education, enable its achievement. It is important to achieve technological literacy in each individual.

Johnson (1989) defines Technology as "the application of knowledge, tools, and skills to solve practical problems and extend human capabilities" (p.13), and states that it is enhanced by the discoveries of science and shaped by the designs of engineering. When defining technology, various researchers (McRobbie, Ginns, and Stein, 2000; Gardner, Penna, and Brass, 1996; Johnson, 1989; Jones and Carr, 1992) point out the following: a) technology is a process; b) it has a human dimension; c) technology is situated (it is conducted within contexts and constraints); d) it includes a social dimension; and (e) it leads to the development of products or artefacts.

For quality teaching of contents related to natural sciences and technology it is essential for teachers to have in-depth knowledge of technology that encompasses all of the five dimensions; while also their conceptions are important.

Research has shown that teachers' beliefs are a strong determinant of teachers' behaviour. Teachers' perceptions of subject discipline and their conceptions of teacher and student role have an important impact on the teachers' decision-making and teaching (Šteh Kure, 1999; Valenčič Zuljan, 2007; Tigchelaar, Brouwer, and Vermunt, 2010). For example, a teacher who saw himself as the guardian of conventional wisdom in science adopted a transmission model of teaching in the classroom and talked about imparting a desired amount of knowledge (McRobbie and Tobin, 1995, as cited in McRobbie, Ginns, "Corresponding author: darjo.zuljan@pef.upr.si 
Zuljan, D., Valenčić Z. M., \& Pejić P. P. (2021). Cognitive constructivist way of teaching scientific and technical contents, International Journal of Cognitive Research in Science, Engineering and Education (IJCRSEE), 9(1), 23-36.

McRobbie, Ginns, and Stein, 2000).

For quality teaching of scientific and technical contents, teachers' didactic competencies are essential. In their review of several studies on learning and meta-studies on teaching efficiency, Dumont and Istance (2013) emphasize how important it is to form efficient and innovative learning environments.

Characteristics of efficient learning environments are: a) in such environments the teacher knows each individual student and performs differentiation and individualization; b) such environments promote optimal mental and emotional activity in each pupil; c) they create collaborative learning and collaborative climate; d) they promote innovativeness and openness and include authentic problems and different ways of research; e) they promote learning of learning and conceive the independence of pupils (Valenčic Zuljan, 2016).

The formation of efficient and innovative learning environments requires professional and well considered selection and complementation of various didactic strategies, teaching methods and ways of working. In their meta-analysis of effective teaching, Marzano, Pickering, and Pollock (2006) refer to the ways of working that have a significant impact on pupils' achievements. They highlight pupil-centred strategies, such as summarizing, taking notes, cooperative learning, setting goals and giving feedback, formulating and testing hypotheses, asking questions and giving cues. Combining various teaching methods and forms of learning to reach predefined goals enables the individualization of learning process, i.e., adapting classes to different pupils (Mattes, 2007; Strmčnik, 2001; Blažič et al., 2003; Plešec Gasparič and Valenčič Zuljan, 2019; Valenčič Zuljan and Kalin, 2020). It is a complex and important competence that develops, according to research findings, during higher stages of teachers' professional development (van der Lans, van de Grift, and van Veen, 2017; Pečar, 2018).

In reference to either earlier studies of 'teacher effectiveness' school or more recent international comparative studies, numerous researchers are pointing at the effectiveness of direct instruction or whole class teaching (Rosenshine, 1979; Reynolds and Farrell, 1996; Miao et al., 2015; Hattie, 2009, 2018; Muijs and Reynolds, 2002). Muijs and Reynolds (2017) define direct instruction as the way of work where the teacher conveys learning contents directly through teaching the whole class, while they point out that this is not only frontal teaching, but also constant autonomous learning work which plays a key role in pupils' effective learning and knowledge. In this context, Valenčič Zuljan and Kalin (2020) use the term traditional teaching (as opposed to open teaching), as they want to emphasize it is classical from the historical point of view, and as they also want to point out the quality of this way of work in attaining certain educational goals. Traditional teaching has proved to be effective to obtain basic knowledge, skills and rules (Brophy and Good, 1986; Good and Brophy, 2003), but less so to acquire more complex and creative contents where the didactic strategies of open teaching are more effective. The term open teaching has been introduced by Strmčnik (2001). Valenčič Zuljan and Kalin (2020) define the term more in detail. They perceive openness from several points of view: openness to recognize and take into account different characteristics of pupils; openness when looking for optimum in terms of pupils' characteristics and teaching contents; openness in the use of sources and spaces; teaching not only in school premises and classrooms but also outside (field work, excursions, outdoor teaching, learning through project work, pupils' research work, authentic learning); openness regarding the cooperation of various profiles of educators and other experts (team teaching, cooperation with researchers, artists, cultural creators, scientists, etc.), openness of the teacher's and pupil's roles (flexible alternating of direct and indirect teaching, teachers can also assume more of a mentor's role, pupils can engage in peer teaching) etc.... and also openness in combining didactic strategies. In order to achieve technological literacy in each pupil, it is thus important for the teacher to make, while taking account of learning goals and contents as well as pupils' characteristics, a professionally well considered selection and combination of didactic strategies (project and problem teaching, problem and traditional teaching, etc.) and to form encouraging and innovative learning environment. As exposed by Vujičić, Pejić-Papak, and ValenčićZuljan (2020, p. 29) "Effective learning setting requires a meaningful combination of individual, frontal and group learning forms, inter-twining pupils' independent work with group work, team cooperation among teachers and other professionals, establishing partner relationship between school and broader environment". When teaching scientific and technical contents, the experientially oriented instruction has an important role. According to Blažič et al. (2003), it has a long tradition, since it was highlighted by educators who derived from empiricism and sensualism (such as Comenius), and educators who relied on rationalism. According to Marks and Walter (1981, as cited in Marentič Požarnik, 1987), the basic premise of experiential learning is that we learn the best when we do something ourselves. Kolb (1984), who developed the experiential learning model, defines the experiential learning as every learning where pupils are in direct contact with reality they study. He emphasizes that this is learning as the process whereby knowledge is created through the transformation of experience. Knowledge results from the 
combination of grasping and transforming experience' (Kolb, 1984, p. 41). "This process is portrayed as an idealized learning cycle or spiral where the learner 'touches all the bases' - experiencing, reflecting, thinking, and acting" (Kolb and Kolb, 2009, p. 44). Various studies on the effects of experientially oriented learning in Science and Technics were carried out at various levels of schooling (Abdulwahed and Nagy, 2009; Dzan et al., 2015; Crompton, 2020; Cotič et al., 2020). Cotič et al. (2020) examined the effect of an experiential learning model (The Mobile Natural Science Learning - MNSL) on the knowledge of 4th grade primary school students in Slovenia, during natural science school lessons at the seashore through the use of tablets. Mobile technology provides authentic learning, assisting outdoor lessons providing material and environmental context in learning, which support the experience of a learner. Findings indicate that the MNSL-model had a positive effect on students' achievement in science, more precisely in knowledge on marine organisms and life at the seashore.

Several researchers studied the impact of instructional methods on students' attitudes toward technology and knowledge (Boser, Palmer, and Daugherty, 1998; Lin et al., 2020). In further text we refer to the examples of studies that in various ways emphasize the importance of connecting various didactic strategies and learning methods.

For the development of scientific and technological literacy it is crucial that learners (children and young people) get familiar with basic scientific and technical conceptions, support them with facts and connect them in a network of knowledge.

In teaching, the explanation method significantly contributes to the clarity and systematic nature of basic conceptions and rules, and the conversation and discussion methods of teaching help verify student's understanding, putting the contents in different perspectives, opening unsolved questions (Valenčič Zuljan and Kalin, 2020), while including inter-subject connections. When teaching scientific and technical contents, drawing and modelling are also important (Valenčič Zuljan and Kalin, 2020; Anning, 1997; Hallström, Elvstrand, and Hellberg, 2015). Mawson (2010) found that opportunities for pupils to draw as a form of technical activity are lacking. As he exposes, learning various techniques of drawing and modelling would enable students to obtain technical language useful to express their ideas. Teaching methods of written works and of work with texts are also important in achieving scientific and technical literacy. Ritchie, Tomas, and Tones (2011) refer to the importance of pupils' activity and creativity in writing and reading. Several researchers (Hand and Prain, 1995, as cited in Ritchie, Tomas, and Tones, 2011; Prain and Hand, 1996, 1999, as cited in Ritchie, Tomas, and Tones, 2011), found that diversified writing tasks, including more imaginative writing, have been shown to assist students' learning processes, improve learning outcomes, have strong motivating effects, and impact positively on students' attitudes and engagement. In this context, the use of student-generated narratives is important. While narrative writing is not traditionally connected to teaching Science and Technics, it attracts pupils and has encouraging effect on them. Wellington and Osborne (2001, as cited in Ritchie, Tomas, and Tones, 2011) think that it helps children express their thoughts in written language through being personally engaged (p. 76), it also offers opportunities to connect personal experiences with science ideas (Hand et al., 2001, as cited in Ritchie, Tomas, and Tones, 2011; Hodson, 2009, as cited in Ritchie, Tomas, and Tones, 2011). Moreover, Avraamidou and Osborne (2009) seriously reflect on the question: How can the conceptual complexity of scientific information be translated into 'everyday' language without minimizing its value? A challenge for teachers, according to Vosniadou et al. (2001) should be the creation of interesting and challenging learning environments where teachers will encourage students to actively participate and direct themselves towards their own goals, building and nurturing the students' natural desire to explore. Mihaliček (2011) states that encouraging learning environment and the use of modern didactic strategies contribute not only to the quality of teaching, but also to the satisfaction of pupils and their teacher. $\mathrm{He}$ exposes it as an important teacher's competence.

McRobbie, Ginns, and Stein (2000) emphasize that teachers should be able to plan and implement learning experiences that would engage students in the generation and evaluation of ideas, and the use and evaluation of design practices to construct a technological artefact. Despite the importance attributed to the teaching method for practical work, activities and products, when pupils make artefacts, get to know various materials and acquire skills within the framework of technology education, the education process should not remain at that level only. Mawson (2007) points that in teaching Science and Technics great emphasis is on making artefacts, while the discussions on broader questions regarding the nature of technology and connections between technology and society are less frequent. (Mawson, 2010, p. 10) The latter is particularly important for the development of pupils' technology literacy.

Twyford and Järvinen (2000) point at the value of problem teaching that "brings authenticity to classroom experiences for pupils". Technological problem solving is a form of reflective thinking in which the child interacts with many sources of knowledge in the process of solving a problem. The pupil's mind 
changes and develops through active participation.

When teaching scientific and technical activities, particularly in younger pupils, the play-based learning method is also important. Boser, Palmer and Daugherty (1998) and Wolters (1989) found the greatest impact on developing a positive attitude toward technology was playing with technological toys, such as LEGOs, Tinkertoys, and Erector Sets.

Turja, Endepohls-Ulpe and Chatoney (2009) have established that not many studies research the play-based method in the context of technological education. When teaching scientific and technical contents to younger pupils, it is possible to apply role playing in various contents: pupils meet various professions, through play, they can get experiences on objects, materials and physical phenomena, through research and tasks, they learn to use tools and accessories (Turja, Endepohls-Ulpe and Chatoney, 2009). There can be individual or group play, which can be (psychomotor) skill-oriented or creative, focused on problem solving etc. Parker-Rees (1997) believes there are structural similarities between free play and design and technological activities, their common feature being encouraging creativity and critical thinking in problem solving. Play can contribute to language development and connecting abstract concepts and ideas with technological objects that are used during play. Free play can stimulate the ability to visualize or a certain kind of cognitive modelling, important in designing and technological activities (Parker-Rees, 1997).

The organization of cognitive-constructivist model of teaching is essential for quality when teaching sciences and technical contents (Yager, 1991; Valenčič Zuljan, 2002, Orbanić Dolenc, Dimec and Cencič, 2016; Akcay and Yager, 2010; Twyford and Jarvinen, 2000; Fox-Turnbull and Snape, 2011). Several studies have shown that cognitive-constructivist model of teaching improves the students' learning outcomes (Kim, 2005; Çalik et al., 2007; Cakici and Yavuz, 2010; Orbanić Dolenc, Dimec and Cencič, 2016) and increases students' interest for science (Parker and Gerber, 2000).

Constructivist views are based on the research performed by many authors, such as Piaget, Vygotsky, Dewey (Marentič Požarnik, 2018). Piaget mostly derived from processes that a person uses to construct the understanding of the world; while Vygotsky - the founder of social constructivism, rather emphasizes the importance of dialogue in knowledge building (Marentič Požarnik and Cencič, 2003). In spite of different views constructivist-oriented researchers have, they share their emphasizing that individuals actively constructs their cognitive structures, when interpreting their own experiences in particular situations (Palincsar, 1998) or that learning means an active mental process, in which pupils themselves transform information into meaningful knowledge (Phillips, 1995). The teachers' role is to design a complex, challenging learning environment with original authentic tasks (Muijs and Reynolds, 2017), and to encourage and accept student autonomy (Moustafa, Ben-Zvi-Assaraf and Eshach, 2013).

It is pupil-oriented teaching (Valenčič Zuljan, 2002; Wilen, Hutchison and Ishler, 2008; Muijs and Reynolds, 2017) that emphasizes the importance of didactic principle of activity and individualization. Therefore, teachers should know children's concepts and experiences in addition to wrong and incomplete perceptions and consider them within the learning process. A teacher forms situations of socio-cognitive conflict and in the process of modelling offers children suitable support in solving the conflict. The teacher's support in cognitive conflict resolution and in the whole process of learning is very important (Valenčic Zuljan, 2002; Manentič Požarnik and Cencič, 2003). For quality learning, children should be able to acquire the knowledge according to different ways and various activities in a stimulating and innovative learning environment with a proper balance between individual and group work, research and discovering, and the teacher's systematic guidance and moderating (Barron and Darling-Hammond, 2013).

\section{Materials and Methods}

Deriving from the meaning of cognitive-constructivist teaching model (Yager, 1991; Akcay and Yager, 2010; Valenčič Zuljan, 2002; Marentič Požarnik, 2004, 2018; Marentič Požarnik and Cencič, 2003; Gojkov, 2009) and various studies on technological education (Mawson, 2007, 2010, 2013; Fleer, 2000; Stables, 1997; Hallström, Elvstrand and Hellberg, 2015), we wanted to know to which extent class teachers include elements of cognitive-constructivist model when teaching scientific and technical contents.

Deriving from the research problem, we formed three research questions:

1. When teaching scientific and technical contents, how often do class teachers introduce elements of cognitive-constructivist model?

2. Is the frequency of implementing elements of cognitive-constructivist teaching model connected to the teachers' concern about their own professional development?

3 . Is the frequency of implementing elements of cognitive-constructivist teaching model connected 
to the following factors: The importance of scientific and technical contents; Need for Science and Technics education; Competence for quality teaching in Science and Technics; Professional enthusiasm, and Complexity of teaching Science and Technics.

In our research, we used quantitative research approach and descriptive and causal nonexperimental method of educational research.

The research included 167 class teachers from various primary schools in the Republic of Slovenia. Data were collected with three scales: a) ways of teaching scientific and technical contents; b) attitude to scientific and technical contents and teaching; c) components of professional development. We used the instrument, developed in the project "Culture of Educational Institution as a Factor in Co-Construction of Knowledge," and adapted it to our needs. 10 new statements were added to the scale Ways of teaching scientific and technical contents that was developed in the project and originally had 6 items. A factor analysis was carried out and Cronbach's reliability coefficients calculated for the new 16 item scale. The Cronbach's alpha reliability coefficients are as follows: the first factor (Importance of scientific and technical contents) .792; the second factor (Need for scientific and technical education) .798; the third factor (Competence for quality scientific and technical education) .674, the fourth factor (Professional enthusiasm) .719; and the fifth factor (Difficulty of teaching Science and Technics) .502.

Data were processed according to descriptive and inferential statistics. The data were processed in the IBM SPSS Statistics Version 27 statistical package. Correlation coefficients $(\rho)$ and factor analysis were used.

Factor analysis was carried out on the scale Attitude towards scientific and technical contents and teaching, consisting of 16 statements. The statements were abstracted into substantively five meaningful factors (KMO $=0.799$; Bartlett's test of Chi-Square sphericity $=927.435$ with $p=.000)$. The method of factor extraction "Principal Component Analysis" was selected. The method of factor rotation is "Varimax with Kaiser Normalisation". The reliability coefficient of this scale is Cronbach's alpha .850. Table 1 presents eigenvalues, explained variances and the number of factors obtained. Table 2 presents the matrix of factors (a set of factors).

\section{Table 1}

Eigenvalues, explained variances and the number of factors obtained

\begin{tabular}{lcccccc}
\hline \multirow{2}{*}{ Component } & \multicolumn{5}{c}{ Initial Eigenvalues } & \multicolumn{3}{c}{ Extraction Sums of Squared Loadings } \\
& Total & \% of Variance & Cumulative \% & Total & \% of Variance & Cumulative \% \\
\hline 1 & 5.231 & 32.693 & 32.693 & 5.231 & 32.693 & 32.693 \\
2 & 1.727 & 10.796 & 43.490 & 1.727 & 10.796 & 43.490 \\
3 & 1.415 & 8.843 & 52.332 & 1.415 & 8.843 & 52.332 \\
4 & 1.112 & 6.952 & 59.284 & 1.112 & 6.952 & 59.284 \\
5 & 1.057 & 6.609 & 65.893 & 1.057 & 6.609 & 65.893 \\
6 & 0.868 & 5.428 & 71.321 & & & \\
7 & 0.775 & 4.844 & 76.164 & & & \\
8 & 0.671 & 4.196 & 80.360 & & & \\
9 & 0.594 & 3.714 & 84.075 & & & \\
10 & 0.565 & 3.531 & 87.605 & & & \\
11 & 0.439 & 2.742 & 90.348 & & & \\
12 & 0.414 & 2.586 & 92.933 & & & \\
13 & 0.345 & 2.154 & 95.088 & & & \\
14 & 0.322 & 2.014 & 97.102 & & & \\
15 & 0.258 & 1.614 & 98.716 & & & \\
16 & 0.206 & 1.284 & 100.000 & & & \\
\hline
\end{tabular}




\section{Table 2}

Matrix of factors (set of factors)

\begin{tabular}{|c|c|c|c|c|c|}
\hline \multirow{2}{*}{ Variables } & \multicolumn{5}{|c|}{ Factors: } \\
\hline & 1 & 2 & 3 & 4 & 5 \\
\hline $\begin{array}{l}\text { Natural and technical sciences are the basis of social development and } \\
\text { progress. }\end{array}$ & 0.850 & & & & \\
\hline $\begin{array}{l}\text { Society progress is based on research in natural and technical scienc- } \\
\text { es. }\end{array}$ & 0.823 & & & & \\
\hline $\begin{array}{l}\text { If a child is successful in learning, it is sensible to guide them towards } \\
\text { natural and technical sciences. }\end{array}$ & 0.644 & 0.458 & & & \\
\hline $\begin{array}{l}\text { The goal of engaging in natural and technical sciences is to enrich gen- } \\
\text { eral human culture. }\end{array}$ & 0.548 & & & 0.357 & 0.308 \\
\hline $\begin{array}{l}\text { Natural sciences and technology in primary school are needed to ena- } \\
\text { ble pupils to decide on their further education. }\end{array}$ & & 0.795 & & & \\
\hline $\begin{array}{l}\text { Science and Technics must be represented in primary-school education } \\
\text { as early as possible. }\end{array}$ & & 0.651 & & 0.525 & \\
\hline $\begin{array}{l}\text { Scientific and technical contents are indispensable for pupils' full devel- } \\
\text { opment. }\end{array}$ & & 0.642 & & 0.541 & \\
\hline $\begin{array}{l}\text { Education in scientific and technical domains is needed to increase } \\
\text { pupils' engagement in solving technology problems of modem society. }\end{array}$ & 0.307 & 0.598 & 0.337 & & \\
\hline $\begin{array}{l}\text { I have enough knowledge to provide pupils quality support in their re- } \\
\text { search and operation of scientific and technical projects within the con- } \\
\text { text of teaching. }\end{array}$ & & & 0.822 & & \\
\hline $\begin{array}{l}\text { In my view, I can properly assist pupils who cannot find a solution when } \\
\text { solving science tasks. }\end{array}$ & & & 0.768 & & \\
\hline $\begin{array}{l}\text { I do fine when I lead discussions related to scientific and technical con- } \\
\text { tents. }\end{array}$ & & & 0.526 & & \\
\hline I am fond of teaching Science and Technics. & & & & 0.801 & \\
\hline I can motivate pupils for scientific and technical contents. & & & 398 & 0.651 & \\
\hline $\begin{array}{l}\text { In my viev, scientific and technical contents are demanding for teach- } \\
\text { ing. }\end{array}$ & & & & & 0.782 \\
\hline $\begin{array}{l}\text { Teaching scientific and technical contents is demanding because of } \\
\text { additional space and material requirements. }\end{array}$ & & & & & 0.770 \\
\hline $\begin{array}{l}\text { Teachers who lack experiences with teaching scientific and technical } \\
\text { contents should receive additional training in this domain. }\end{array}$ & & 0.319 & 0.356 & & 0.395 \\
\hline
\end{tabular}

Note: Extraction method: Principal Component Analysis. Rotation method: Varimax with Kaiser Normalization.

The table shows only values above 0.2 . Factor loadings are bold.

\section{Descriptions of factors obtained}

Factor 1 - entitled Importance of scientific and technical contents explains $32.693 \%$ variance of factor space. Factor 2 - entitled Need for scientific and technical education explains $10.796 \%$ of total variance. Factor 3 - entitled Competence for quality scientific and technical education explains $8.843 \%$ of total variance. Factor 4 - entitled Professional enthusiasm explains $6.952 \%$ of total variance. Factor 5 - entitled Difficulty of teaching Science and Technics explains $6.609 \%$ of total variance. 


\section{Results}

Frequency of implementing various elements of cognitive constructivist way of teaching scientific and technical contents

Teachers assessed 6 statements that defined elements of cognitive constructivist way of teaching scientific and technical contents. Since the cognitive constructivist way of teaching points out mental activities of pupils, all the statements were designed so that they originated in the descriptions deriving from pupils' activities.

When forming individual statements we relied on various descriptions of cognitive constructivist model (Sparks-Langer et.al., 2000; Valenčič Zuljan, 2002), that emphasize the importance of pupils' activities in collecting information to test hypotheses, in reflective observation and asking questions, formation of hypotheses, performance of various experiments, verification of hypotheses, as well as the analysis and generalization of conclusions.

Table 3

The shares of assessed frequency of implementing various elements in teaching scientific and technical contents

\begin{tabular}{|c|c|c|c|c|c|c|c|}
\hline & & 1 & 2 & 3 & 4 & 5 & \\
\hline Statement: & & I never & I rarely & I do at & I often & I do very & $M$ \\
\hline PUPILS & & do & do & times & do & often & $S D$ \\
\hline \multirow{2}{*}{$\begin{array}{l}\text { 1. Perceive phenomena and ask ques- } \\
\text { tions. }\end{array}$} & $f$ & 1 & 2 & 30 & 95 & 41 & 4.02 \\
\hline & $f(\%)$ & 0.6 & 1.2 & 17.8 & 56.2 & 24.3 & 0.72 \\
\hline \multirow{2}{*}{$\begin{array}{l}\text { 2. Collect information with research } \\
\text { problem tasks. }\end{array}$} & $f$ & 2 & 7 & 56 & 90 & 14 & 3.63 \\
\hline & $f(\%)$ & 1.2 & 4.1 & 33.1 & 53.3 & 8.3 & 0.74 \\
\hline 3. Formulate assumptions (hypotheses) & $f$ & 9 & 61 & 81 & 17 & 1 & 3.63 \\
\hline $\begin{array}{l}\text { on possible answers to questions or so- } \\
\text { lutions to problems. }\end{array}$ & $f(\%)$ & 5.3 & 36.1 & 47.9 & 10.1 & 0.6 & 0.74 \\
\hline \multirow[t]{2}{*}{ 4. Examine assumptions } & $f$ & 4 & 35 & 99 & 29 & 2 & 3.91 \\
\hline & $f(\%)$ & 2.4 & 20.7 & 58.6 & 17.2 & 1.2 & 0.68 \\
\hline \multirow[t]{2}{*}{ 5. Carry out experiments. } & $f$ & 1 & 7 & 43 & 81 & 37 & 3.86 \\
\hline & $f(\%)$ & 0.6 & 4.1 & 25.4 & 47.9 & 21.9 & 0.82 \\
\hline 6. Analyze obtained results and draw & $f$ & 3 & 41 & 87 & 37 & 1 & 3.94 \\
\hline conclusions. & $f(\%)$ & 1.8 & 24.3 & 51.5 & 21.9 & 0.6 & 0.73 \\
\hline
\end{tabular}

The table 3 shows that in no item grade 5 appears in the first position - I do very often (regularly), somewhat higher rate appears in items Pupils perceive phenomena and ask questions $(24.3 \%)$ and Pupils carry out experiments (21.9\%).Grade 4 - I do often appears in the first position / with the highest share in three items: Pupils perceive phenomena and ask questions (56.2\%), Pupils collect information with research problem tasks (53.0\%) and Pupils carry out experiments (47.9\%). Grade 3 - I do at times figures first in three items: Pupils formulate assumptions (hypotheses) on possible answers to questions or solutions to problems (47.9\%); Pupils examine assumptions (58.6\%), and Pupils analyze obtained results and draw conclusions (51.5\%). Grade 2 - I do rarely has a somewhat higher share in three items: Pupils formulate assumptions (hypotheses) on possible answers to questions or solutions to problem (36.1\%); Pupils examine assumptions (20.7\%), and Pupils analyze obtained results and draw conclusions $(24.3 \%)$.

Is the frequency of implementing various elements of cognitive-constructivist way of teaching scientific and technical contents connected to teachers' concern of their own professional development?

We wanted to know whether the frequency of implementing various elements of cognitiveconstructivist way of teaching scientific and technical contents was connected to the teachers' concern of their own professional development, and this was covered in two items: using new scientific research 
findings in the domain of learning, teaching and other subject matter and reflecting on their own pedagogical practice.

\section{Table 4}

Assessing items on teachers' concern of their own professional development

\begin{tabular}{|c|c|c|c|c|c|c|c|}
\hline \multirow[b]{2}{*}{ Statement: } & & 1 & 2 & 3 & 4 & 5 & \\
\hline & & Not typi- & Mostly not & I cannot & Mostly & Absolutely & M \\
\hline In my work, I use new scientific & $f$ & 1 & 9 & 30 & 109 & 19 & 3.80 \\
\hline $\begin{array}{l}\text { research findings from the domains } \\
\text { of learning, teaching and other } \\
\text { subject matter. }\end{array}$ & $f(\%)$ & 0.6 & 5.3 & 17.8 & 64.5 & 11.2 & 0.72 \\
\hline I regularly reflect on my own & $f$ & 1 & 9 & 41 & 95 & 22 & 3.76 \\
\hline pedagogical practice. & $f(\%)$ & 0.6 & 5.3 & 24.3 & 56.2 & 13.0 & 0.76 \\
\hline
\end{tabular}

In both items grade 4 occupies the largest share (Table 4) - Mostly typical $64.5 \%$ of teachers estimate to be "mostly" typical for them to use new scientific research findings from the domains of learning, teaching and other subject matter, and $56.2 \%$ to be mostly typical for them to regularly reflect on their own pedagogical practice. Grade 5 - absolutely typical with its share of $11.2 \%$ appears for item "In my work, I use new scientific research findings from the domains of learning, teaching and other subject matter" and with $24.3 \%$ share for the statement I regularly reflect on my own pedagogical practice.

Table 5

Correlation coefficient ( $\rho$ ) between the teacher's concern for their own professional development and the frequency of implementing various ways of teaching scientific and technical contents

\begin{tabular}{|c|c|c|c|}
\hline Elements: PUPILS & & Using new findings & Reflecting on their own practice \\
\hline \multirow{3}{*}{$\begin{array}{l}\text { 1. Perceive phenomena and ask ques- } \\
\text { tions }\end{array}$} & $\rho$ & $.181^{*}$ & $.222^{* \star}$ \\
\hline & $p$ & .019 & .004 \\
\hline & $N$ & 167 & 168 \\
\hline \multirow{3}{*}{$\begin{array}{l}\text { 2. Collect information with research prob- } \\
\text { lem tasks }\end{array}$} & $\rho$ & .106 & $.218^{* k}$ \\
\hline & $p$ & .172 & .004 \\
\hline & $N$ & 167 & 168 \\
\hline 3. Formulate assumptions (hypotheses) & $\rho$ & .080 & $.251^{* \star}$ \\
\hline \multirow{2}{*}{$\begin{array}{l}\text { on possible answers to questions or solu- } \\
\text { tions to problems }\end{array}$} & $p$ & .306 & .001 \\
\hline & $N$ & 166 & 167 \\
\hline \multirow{3}{*}{ 4. Examine assumptions } & $\rho$ & $.197^{\circ}$ & $.213^{* \star}$ \\
\hline & $p$ & .011 & .006 \\
\hline & $N$ & 165 & 166 \\
\hline \multirow{3}{*}{ 5. Carry out experiments } & $\rho$ & $.153^{*}$ & .093 \\
\hline & $p$ & .049 & .233 \\
\hline & $N$ & 167 & 168 \\
\hline \multirow{3}{*}{$\begin{array}{l}\text { 6. Analyze obtained results and draw } \\
\text { conclusions. }\end{array}$} & $\rho$ & $.244^{* *}$ & .151 \\
\hline & $p$ & .002 & .052 \\
\hline & $N$ & 166 & 167 \\
\hline
\end{tabular}

${ }^{\star} p<.05{ }^{* *} p<.01$.

Teachers who regularly reflect on their own pedagogical practice, statistically significantly more often organize classes, where pupils perceive phenomena and ask questions $(p=.004)$; collect information with 
research problem tasks ( $p=.004$; formulate assumptions (hypotheses) on possible answers to questions or solutions to problems ( $p=.001)$; and examine assumptions $(p=.006)$. Teachers who teach using new scientific research findings from the domains of learning, teaching and other subject matter, statistically significantly more often organize classes, where pupils perceive phenomena and ask questions $(p=$ $.019)$; examine assumptions ( $p=.011)$; carry out experiments $(p=.049)$; and analyze obtained results and draw conclusions $(p=.002)$ (Table 5).

Correlations between factors and the frequency of implementing various elements of cognitive constructivist way of teaching scientific and technical contents

We were interested whether factors Importance of scientific and technical contents (factor 1); Need for scientific and technical education (factor 2); Competence for quality scientific and technical education (factor 3); Professional enthusiasm (factor 4), and Difficulty of teaching Science and Technics (factor 5) are statistically significantly connected to the frequency of implementing various elements of cognitive constructivist way of teaching.

Table 6

Correlation coefficients $(\rho)$ between factors and the frequency of implementing various ways of teaching scientific and technical contents

\begin{tabular}{lcccccc}
\hline & \multicolumn{5}{c}{ Factor: } \\
\cline { 2 - 7 } Elements: PUPILS & & 1 & 2 & 3 & 4 & 5 \\
\hline \multirow{3}{*}{ 1. Perceive phenomena and ask questions } & $\rho$ & -.089 & .064 & $.251^{* *}$ & $.200^{*}$ & .130 \\
& $p$ & .259 & .415 & .001 & .010 & .098 \\
& $N$ & 163 & 163 & 163 & 163 & 163 \\
\hline 2. Collect information with research prob- & $\rho$ & .038 & .117 & $.290^{* *}$ & .129 & .030 \\
lem tasks & $p$ & .633 & .136 & .000 & .099 & .705 \\
& $N$ & 163 & 163 & 163 & 163 & 163 \\
\hline 3. Formulate assumptions (hypotheses) on & $\rho$ & .004 & .010 & $.250^{* *}$ & .131 & .074 \\
possible answers to questions or solutions & $p$ & .962 & .895 & .001 & .098 & .347 \\
to problems & $N$ & 162 & 162 & 162 & 162 & 162 \\
\hline \multirow{4}{*}{ 4. Examine assumptions } & $\rho$ & .021 & .125 & $.210^{* *}$ & $.196^{*}$ & $.266^{* *}$ \\
& $p$ & .795 & .113 & .007 & .013 & .001 \\
& $N$ & 161 & 161 & 161 & 161 & 161 \\
\hline \multirow{3}{*}{ 5. Carry out experiments } & $\rho$ & .109 & -.017 & $.188^{*}$ & $.291^{* *}$ & .110 \\
& $p$ & .165 & .827 & .016 & .000 & .161 \\
\hline 6. Analyze obtained results and draw con- & $\rho$ & .011 & .027 & $.257^{* *}$ & $.198^{*}$ & $.196^{*}$ \\
clusions. & $p$ & .890 & .737 & .001 & .012 & .013 \\
& $N$ & 162 & 162 & 162 & 162 & 162 \\
\hline
\end{tabular}

${ }^{\star} p<.05 .{ }^{* \star} p<.01$

Table 6 shows there are no statistically significant connections between factor 1 Importance of scientific and technical contents and the elements of implementing cognitive constructivist way of teaching scientific and technical contents. Neither are there statistically significant connections between factor 2 Need for scientific and technical education and the elements of implementing cognitive constructivist way of teaching scientific and technical contents.

Factor 3 competence for quality scientific and technical education is statistically significantly connected to all six elements. Teachers who rate higher their competences to teach Science and Technics, statistically significantly more often organize classes where pupils perceive phenomena and ask questions $(p=.001)$; collect information with research problem tasks $(p=.000)$; formulate assumptions (hypotheses) on possible answers to questions or solutions to problems $(p=.001)$; examine assumptions $(p=.007)$; 
carry out experiments/tests $(p=.016)$; analyze obtained results and draw conclusions $(p=.001)$. Factor 4 Professional enthusiasm is statistically significantly connected to four elements. Teachers who express a higher degree of enthusiasm, statistically significantly more often organize classes where pupils perceive phenomena and ask questions ( $p=.010)$; examine assumptions $(p=.013)$; carry out experiments/tests $(p=.000)$; analyze obtained results and draw conclusions $(p=.012)$. Factor 5 Difficulty of teaching Science and Technics is statistically significantly connected to two elements. Teachers who rate higher the difficulty of teaching Science and Technics, statistically significantly more often organize classes where pupils examine assumptions $(p=.001)$; analyze obtained results and draw conclusions $(p=.013)$.

\section{Discussions}

To achieve high-quality knowledge of pupils it is crucial to respect the didactic principle of learning activity. Cognitive constructivist teaching model is based on the assumption that pupils actively build the system of their own knowledge, with teachers having the role of providing adapted cognitive in emotional support. In our research, pupils' activities are covered in 6 elements of cognitive constructive model. We found out that out of the six elements of cognitive constructivist teaching model, teachers often organized activities where pupils perceive phenomena and ask questions $(56.2 \%)$, collect information with research problem tasks (53.\%) and carry out tests (47.9\%). Activities where pupils formulate assumptions (hypotheses) on possible answers to questions or solutions to problems $(47.9 \%)$; where pupils examine assumptions (58.6\%) and where they analyze obtained results and draw conclusions (51.5) were carried out occasionally. It has to be pointed out that grade 2-I do rarely has a somewhat higher share in three items: pupils formulate assumptions (hypotheses) on possible answers to questions or solutions to problem (36.1\%); pupils examine assumptions (20.7\%), and pupils analyze obtained results and draw conclusions $(24.3 \%)$.

The research showed that the elements of cognitive constructivist way of teaching scientific and technical contents were more often organized by teachers who rated higher their competence. The importance of competent teachers for quality implementation of their professional role is confirmed in numerous studies (Brophy and Good, 1986; Marzano, Pickering and Pollock, 2006; Hattie, 2009, 2018; Darling-Hammond and Richardson, 2009). Deriving from the obtained results, it is important that already during their studies students have opportunities to obtain insights into characteristics of cognitive constructivist way of teaching and develop skills of forming a cognitive conflict and of scaffolding as basic characteristics of cognitive constructivist model. The very elements of formulating hypotheses and their examination are the items for which a greater share of teachers claim their rare implementation. It is necessary to emphasize that cognitive conflict and providing scaffolding for pupils who have various capabilities, previous knowledge and motivation requires from teachers to observe the didactic principle of learning differentiation and individualization.

If students are to be trained in cognitive constructivist way of teaching scientific and technical contents, it is important that they themselves receive this way of teaching during their studies (Richardson, 1997; Valenčič Zuljan, 2007). In this context, didactic strategies of "open teaching" are important - such as problem-based approach, project work, research teaching. Numerous studies point out the importance of problem-based approach (Roth, 1995, as cited in McRobbie, Ginns and Stein, 2000; McCormick et al., 1996, as cited in McRobbie, Ginns and Stein, 2000) for heightening the awareness of technology and technology education. (Andersno \& Walvoord, 1990, 1993, as cited in McRobbie, Ginns and Stein, 2000; Shapiro, 1996; Swain, 1991; Tyler, 1992). "The problem-solving access to educational content is always in the function of enabling students to experience, understand and evaluate the content that is being studied." (Mezak and Pejić Papak, 2019). Organization and teaching procedures should be chosen to maximize and sustain the student's thought activity and contribute to their conclusions and decision abilities.

McRobbie, Ginns and Stein (2000) carried out an investigation, using an interpretive research methodology, of preservice primary teachers' prior perceptions of design and technology and changes in their perceptions of design and technology as a result of their engagement in independent technology projects. In the research, there were 130 participants, enrolled in a one-year postgraduate teacher education program. Research findings confirmed the importance of including independent technology projects in courses for preservice primary teachers as a way of changing their perceptions of technology and technology education. Numerous studies (Anderson \& Walvoord, 1990, 1993, as cited in McRobbie, Ginns and Stein, 2000; Shapiro, 1996; Swain, 1991; Tyler, 1992) confirm that engagement in independent investigations can stimulate changes in students' thinking and a broader understanding of technology. 
What is crucial is the experiential learning of students future teachers through current open downtoearth problems, as this contributes to a deeper personal understanding of learning contents and increased professional enthusiasm.

The research showed that teachers with a higher level of enthusiasm statistically significantly more often carried out elements of cognitive constructivist teaching model and more often organized classes where pupils perceive phenomena and ask questions; examine assumptions; carry out tests, and analyze obtained results and draw conclusions. The importance of teacher's enthusiasm has been confirmed in numerous studies (Rosenshine, 1970; Rosenshine and Furst, 1973; Brophy and Good, 1986; Patrick et al., 2003; Turner et al., 1998). Brophy and Good (1986) define "teacher enthusiasm" as one of the teacher qualities that significantly influences effective teaching. Rosenshine (1970), and Rosenshine and Furst (1973) established that teacher's enthusiasm and passion for the subject they teach correlate with pupils' achievements. Therefore it is important for students and teachers to be familiar with studies on the impact of teacher's enthusiasm, and also to research their own teaching in the perspective of the influence of enthusiasm on pupils. Lončarić and Pejić Papak (2009) emphasize the importance of teacher's research, which positively influences their professional commitment. Teachers' research is also an important factor of their professional development (Marentič Požarnik, 2018; Vogrinc and Valenčič Zuljan, 2009; Valenčič Zuljan, 2018).

The research showed no statistically significant differences between the frequency of implementing elements of cognitive constructivist way of teaching scientific and technical contents and factors Importance of scientific and technical contents and Need for scientific and technical education. We found out that teachers who rate higher the difficulty of teaching scientific and technical contents statistically significantly more often implement two of the six elements of cognitive constructivist model of teaching, namely they more often organize classes where pupils examine assumptions; analyze obtained results and draw conclusions.

Our research showed that the elements of cognitive constructivist way of teaching are more often organized by teachers with greater concern of their professional development, in our research measured with observance of new scientific research findings referring to learning, teaching and other subject matter as well as the reflection on their own pedagogic practice. In view of our study findings and the fact that professional development presents one of the basic competences of the modern teacher, it is important that already during their studies students future teachers are familiarized with the research on teacher's professional development and raised to awareness that taking care of their professional development is a basic value.

\section{Conclusions}

The results of our study lead to the conclusion that all 6 elements of cognitive constructivist way of teaching should be strengthened, since grade 5 - (very often) does not have a high share in any element, which however would be expected given the importance of cognitive constructivist way of teaching scientific and technical contents. For quality teaching of natural and technical contents, the share of the following three items should particularly be strengthened: Pupils formulate assumptions (hypotheses) on possible answers to questions or solutions to problem; Pupils examine assumptions, and Pupils analyze obtained results and draw conclusions.

Data from our research lead to the conclusion that the frequency of implementing elements of cognitive constructivist teaching model is linked to the teachers' concern for their own professional development, since those who use new scientific research findings in their work and regularly reflect on their own pedagogical practice, statistically significantly more often organize elements (4 to 6 ) of cognitive constructivist way of teaching.

The research showed that the frequency of implementing elements of cognitive constructivist way of teaching is statistically significantly connected to 3 out of 5 factors: Competence for quality scientific and technical education (in all 6 elements); Professional enthusiasm (in 4 elements), and Difficulty of teaching Science and Technics (in 2 elements).

It would be sensible to continue research, which would additionally help shed light on the reasons for the findings of our study, among others class teachers' attitudes to the importance of cognitive constructivist way of teaching, what obstructs them in introducing this way of work, in which elements they would need additional support at the level of school or support in additional education at the system level, etc. 


\section{Acknowledgements}

We would like to express our gratitude to all the teachers who participated in the survey.

\section{Conflict of interests}

The authors declare no conflict of interest.

\section{References}

Abdulwahed, M., \& Nagy, Z. K. (2009). Applying Kolb's experiential learning cycle for laboratory education. Journal of engineering education, 98(3), 283-294. https://doi.org/10.1002/j.2168-9830.2009.tb01025.x

Akcay, H., \& Yager, R. E. (2010). The impact of a science/technology/society teaching approach on student learning in five domains. Journal of Science Education and Technology, 19(6), 602-611. https://doi.org/10.1007/s10956-010-9226-7

Anning, A. (1997). Drawing out ideas: Graphicacy and young children. International Journal of Technology and Design Education, 7(3), 219-239. https://doi.org/10.1023/A:1008824921210

Avraamidou, L., \& Osborne, J. (2009). The role of narrative in communicating science. International Journal of Science Education, 31, 1683-1707. https://doi.org/10.1080/09500690802380695

Barron, B., \& Darling-Hammond, L. (2013). Prospects and challenges for inquiry-based approaches to learning. In H. Dumont, D. Istance \& F. Benavides (Eds.), The nature of learning: Using research to inspire practice (pp. 183-205). Ljubljana: Zavod Republike Slovenije za šolstvo.

Blažič, M., Ivanuš Grmek, M., Kramar, M. \& Strmčnik, F. (2003). Didaktika [Didactics]. Novo mesto: Visokošolsko središče.

Boser, R. A., Palmer, J. D., \& Daugherty, M. K. (1998). Students attitudes towards technology in selected technology education programs. Journal of Technology Education, 10(1), 4-19 https://doi.org/10.21061/jte.v10i1.a.1

Brophy, J., \& Good, T. L. (1986). Teacher behavior and student achievement. In M. Wittrock (Ed.), Handbook of research on teaching (pp. 340-370). New York: Macmillan Library.

Cakici, Y., \& Yavuz, G. (2010). The effect of constructivist science teaching on 4th Grade students' understanding of matter. AsiaPacific Forum on Science Learning and Teaching, 11(2), 1-8.

Çalik, M., Ayas, A., Coll, R. K., Ünal, S., \& Coştu, B. (2007). Investigating the effectiveness of a constructivist-based teaching model on student understanding of dissolution of gases in liquids. Journal of Science Education and Technology, 16(3), 257-270. https://doi.org/10.1007/s10956-006-9040-4

Cotič, N., Plazar, J., Starčič, A. I., \& Zuljan, D. (2020). The effect of outdoor lessons in natural sciences on students' knowledge, through tablets and experiential learning. Journal of Baltic Science Education, 19(5), 747. https://doi.org/10.33225/ jbse/20.19.747

Crompton, H. (2020). Contextualizing STEM Learning: Frameworks \& Strategies. Research on Outdoor STEM Education in the digiTal Age, 13.

Darling-Hammond, L., \& Richardson, N. (2009). Research review/teacher learning: What matters. Educational leadership, 66(5), 46-53. Retrieved from https://outlier.uchicago.edu/computerscience/OS4CS/landscapestudy/resources/DarlingHammond-and-Richardson-2009.pdf

Dumont, H., \& Istance, D. (2013). Analysing and designing learning environments for the 21 st century. In H. Dumont, D., Istance \& F. Benavides (Eds.), The nature of learning: Using research to inspire practice (pp. 19-34). Ljubljana: Zavod Republike Slovenije za šolstvo.

Dzan, W. Y., Tsai, H. Y., Lou, S. J., \& Shih, R. C. (2015). Satisfaction analysis of experiential learning-based popular science education. International Journal of Distance Education Technologies (IJDET), 13(2), 93-109. https://doi.org/10.4018/ ijdet.2015040106

Fleer, M. (2000). Working technologically: Investigations into how young children design and make during technology education. International Journal of Technology and Design Education, 10(1), 43-59. https://doi.org/10.1023/a:1008923410441

Fox-Turnbull, W., \& Snape, P. (2011). Technology teacher education through a constructivist approach. Design and Technology Education: An International Journal, 16(2).

Gardner, P. J., Penna, C., \& Brass, K. (1996). 'Technology education in the post-compulsory years'. In P. J. Fensham (Ed.), Science and Technology Education in the Post-Compulsory Years (pp. 140-192). Australian Council of Educational Research, Melbourne.

Gojkov, G. (2009). Didaktika i metakognicija [Didactics and metacognition]. Vršac: Visoka škola strukovnih studija za obrazovanje.

Good, T. L., \& Brophy, J. E. (2003). Looking in classrooms (9th ed.). Boston, MA: Allyn et Bacon.

Hallström, J., Elvstrand, H., \& Hellberg, K. (2015). Gender and technology in free play in Swedish early childhood education. International Journal of Technology and Design Education, 25(2), 137-149. https://doi.org/10.1007/s10798-014-9274-z

Hattie, J. (2009). Visible learning: a synthesis of over 800 meta-analyses relating to achievement. London: Rutledge.

Hattie, J. (2018). Vidno učenje za učitelje: maksimiranje učinka na učenje [Visual learning for teachers: maximizing the impact on learning]. Griže: Svetovalno-izobraževalni center Ml.

Johnson, J. R. (1989). Technology: report of the project 2061 phase 1 technology panel. American Association for the Advancement of Science, Washington, DC.

Jones, A. \& Carr, M. (1992). Teachers' perceptions of technology education: Implications for curriculum innovation. Research in Science Education, 22, 230-239. https://doi.org/10.1007/bf02356900

Kim, J. S. (2005). The effects of a constructivist teaching approach on student academic achievement, self-concept, and learning strategies. Asia Pacific Education Review, 6(1), 7-19. https://doi.org/10.1007/bf03024963

Kolb, A. Y., \& Kolb, D. A. (2009). Experiential learning theory: A dynamic, holistic approach to management learning, education 
and development. The SAGE handbook of management learning, education and development, 42, 68. https://doi. org/10.4135/9780857021038.n3

Kolb, D. A. (1984). Experiential learning. Englewood Cliffs: Prentice-Hall.

Lin, K. Y., Hsiao, H. S., Williams, P. J., \& Chen, Y. H. (2020). Effects of 6E-oriented STEM practical activities in cultivating middle school students' attitudes toward technology and technological inquiry ability. Research in Science \& Technological Education, 38(1), 1-18. https://doi.org/10.1080/02635143.2018.1561432

Lončarić, D., \& Pejić Papak, P. (2009). Profiliranje učiteljskih kompetencija [Profiling of teacher competencies]. Odgojne znanosti, 11(2), 479-497.

Marentič Požarnik, B. (1987). Nova pota v izobraževanju učiteljev [A new path in teacher education]. Ljubljana: Državna založba Slovenije.

Marentič Požarnik, B. (2004). Konstruktivizem v šoli in izobraževanje učiteljev [Constructivism in school and teacher education]. Ljubljana: Center za pedagoško izobraževanje Filozofske fakultete.

Marentič Požarnik, B. (2018). Psihologija učenja in pouka [Psychology of learning and teaching]. Ljubljana: DZS.

Marentič Požarnik, B., \& Cencič, M. (2003). Konstruktivizem v izobraževanju [Constructivism in education]. Pedagoška obzorja, 18(2), 34-39

Marzano, R. J., Pickering, D. J., \& Pollock, J. E. (2006). Nastavne strategije: kako primijeniti devet najuspješnijih nastavnih strategija [Teaching strategies: how to apply the nine most successful teaching strategies]. Zagreb: Educa.

Mattes, W. (2007). Nastavne metode: 75 kompaktnih pregleda za nastavnike i učenike [Teaching methods: 75 compact reviews for teachers and students]. Zagreb: Naklada Ljevak.

Mawson, B. (2007). Factors affecting learning in technology in the early years at school. International Journal of Technology and Design Education, 17(3), 253-269. https://doi.org/10.1007/s10798-006-9001-5

Mawson, B. (2010). Children's developing understanding of technology. International Journal of Technology and Design Education, 20(1), 1-13. https://doi.org/10.1007/s10798-008-9062-8

Mawson, W. B. (2013). Emergent technological literacy: what do children bring to school?. International Journal of Technology and Design Education, 23(2), 443-453. https://doi.org/10.1007/s10798-011-9188-y

Moustafa, A., Ben-Zvi-Assaraf, O., \& Eshach, H. (2013). Do junior high school students perceive their learning environment as constructivist?. Journal of Science Education and Technology, 22(4), 418-431. https://doi.org/10.1007/s10956-0129403-y

McRobbie, C. J., Ginns, I. S., \& Stein, S. J. (2000). Preservice primary teachers' thinking about technology and technology education. International Journal of Technology and Design Education, 10(1), 81-101. https://doi. org/10.1023/A:1008941520152

Mezak, J., \& Papak, P. P. (2019, May). Problem based learning for primary school junior grade students using digital tools. In $201942^{\text {nd }}$ International Convention on Information and Communication Technology, Electronics and Microelectronics (MIPRO) (pp. 697-702). IEEE. https://doi.org/10.23919/MIPRO.2019.8756775

Miao, Z., Reynolds, D., Harris, A., \& Jones, M. (2015). Comparing performance: a cross-national investigation into the teaching of mathematics in primary classrooms in England and China. Asia Pacific Journal of Education, 35(3), 392-403. https:// doi.org/10.1080/02188791.2015.1056593

Mihaliček, S. (2011). Zadovoljstvo i sreća učitelja [Teacher satisfaction and happiness]. Napredak: Časopis za interdisciplinarna istraživanja u odgoju i obrazovanju, 152(3-4), 389-402. Retrieved from https://hrcak.srce.hr/82782

Muijs, D., \& Reynolds, D. (2002). Teachers' beliefs and behaviors: What really matters? The Journal of Classroom Interaction, 37(2), 3-15.

Muijs, D., \& Reynolds, D. (2017). Effective teaching: Evidence and practice. Sage. Retrieved from https://1filedownload.com/ wp-content/uploads/2019/12/040-Effective-Teaching-Evidence-And-Practice.pdf

Orbanić Dolenc, N., Dimec, D. S., \& Cencič, M. (2016). The effectiveness of a constructivist teaching model on student's understanding of photosynthesis. Journal of Baltic science education, 15(5). Retrieved from https://sisu.ut.ee/sites/ default/files/opikasitus/files/orbanic_dimec_cencic_2016._the_effectiveness_of_a_constructivist_teaching_model_ on_students_understanding_of_photosynthesis.pdf

Palincsar, $\bar{A}$. S. (1998). Social constructivist perspectives on teaching and learning. Annual review of psychology, 49(1), 345375. Retrieved from https://www.annualreviews.org/doi/abs/10.1146/annurev.psych.49.1.345

Parker, V., \& Gerber, B. (2000). Effects of a science intervention program on middle-grade student achievement and attitudes. School Science and Mathematics, 100(5), 236-242. https://doi.org/10.1111/j.1949-8594.2000.tb17263.x

Parker-Rees, R. (1997). Learning from play: Design and technology, imagination and playful thinking. IDATER 1997 conference (pp. 20-25). Loughborough: Loughborough University.

Patrick, H., Turner, J. C., Meyer, D. K., \& Midgley, C. (2003). How teachers establish psychological environments during the first days of school: Associations with avoidance in mathematics. Teachers College Record, 105(8), 1521-1558. Retrieved from https://users.ugent.be/ wbeyers/scripties2016/artikels/Patrick\%20\&\%20Turner\%202003.pdf

Pečar, M. (2018). Izkušnje in stališča učiteljev o prilagajanju pouka predznanju in interesom učencev: doktorska disertacija [Teachers 'experiences and attitudes towards adapting lessons to students' prior knowledge and interests: doctoral dissertation] [Doctoral dissertation], Univerza v Ljubljani, Pedagoška fakulteta.

Plešec, G. R. \& Zuljan, M. V. (2019). Učne oblike v osnovni šoli in obrnjeno učenje in poučevanje [Learning forms in primary school and reverse learning and teaching]. Journal of

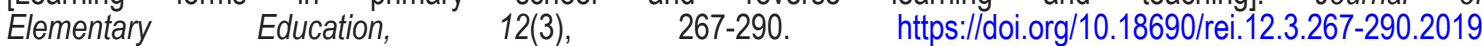

Phillips, D. C. (1995). The good, the bad, and the ugly: The many faces of constructivism. Educational Researcher, 24(7), 5-12. https://doi.org/10.3102/0013189X024007005

Reynolds D., \& Farrell, S. (1996). Worlds Apart? A Review of International Studies of Educational Achivement Involving England. London: HMSO.

Richardson, V. (Ed.). (1997). Constructivist teacher education: Building new understandings. Psychology Press.

Ritchie, S. M., Tomas, L., \& Tones, M. (2011). Writing stories to enhance scientific literacy. International Journal of Science Education, 33(5), 685-707. https://doi.org/10.1080/09500691003728039

Rosenshine, B. (1970). Enthusiastic teaching: A research review. The School Review, 78(4), 499-514. Retrieved from https:// 
www.journals.uchicago.edu/doi/abs/10.1086/442929?journalCode=schoolreview

Rosenshine, B. (1979). Content, time, and direct instruction. Research on teaching: Concepts, findings, and implications. In P. Peterson \& H. Walberg (Eds.), Research on teaching: Concepts, findings and implications (pp. 28-56). Berkeley, CA: McCutchan.

Rosenshine, B., \& Furst, N. (1973). The use of direct observation to study teaching. In R. Travers (Ed.), Second handbook of research on teaching (pp.122-183). Chicago: Rand McNally.

Shapiro, B. L. (1996). A case study of change in elementary student teacher thinking during an independent investigation in science: Learning about the "face of science that does not yet know". Science Education, 80(5), 535-560. https://doi. org/10.1002/(SICI)1098-237X(199609)80:5<535::AID-SCE3>3.0.CO;2-C

Sparks-Langer, G. M., Pasch, M., Starko, A. J., Moody, C. D. \& Gardner, T. G. (2000). Teaching as decision making: successful practices for the secondary teacher. Merrill Prentice Hall.

Stables, K. (1997). Critical issues to consider when introducing technology education into the curriculum of young learners. Journal of Technology Education, 8(2). https://doi.org/10.21061/jte.v8i2.a.4

Šteh Kure, B. (1999). Pojmovanja učenja, poučevanja in znanja v povezavi z učnim procesom in uspehom [Concepts of learning, teaching and knowledge in relation to the learning process and success]. Sodobna pedagogika, 50(1), 250265.

Strmčnik, F. (2001). Didaktika: osrednje teoretične teme [Didactics: central theoretical topics]. Ljubljana: Znanstveni inštitut Filozofske fakultete.

Swain, J. R. L. (1991). The nature and assessment of scientific explorations in the classroom. School Science Review, 72(260), 65-77.

Tigchelaar, A., Brouwer, N., \& Vermunt, J. D. (2010). Tailor-made: Towards a pedagogy for educating second-career teachers. Educational Research Review, 5(2), 164-183. https://doi.org/10.1016/j.edurev.2009.11.002

Turja, L., Endepohls-Ulpe, M., \& Chatoney, M. (2009). A conceptual framework for developing the curriculum and delivery of technology education in early childhood. International Journal of Technology and Design Education, 19(4), 353-365. https://doi.org/10.1007/s10798-009-9093-9

Turner, J. C., Meyer, D. K., Cox, K. E., Logan, C., DiCintio, M., \& Thomas, C. T. (1998). Creating contexts for involvement in mathematics. Journal of Educational Psychology, 90(4), 730-745. https://doi.org/10.1037/0022-0663.90.4.730

Twyford, J., \& Järvinen, E. M. (2000). The formation of children's technological concepts: A study of what it means to do technology from a child's perspective. Journal of Technology Education, 12(1), 32-48. Retrieved from https://vtechworks. lib.vt.edu/bitstream/handle/10919/8248/twyford.pdf?sequence=1

Tyler, R. (1992). Independent research projects in school science: Case studies of autonomous behavior. International Journal of Science Education, 14, 393-411.

Valenčić Zuljan, M. (2016). Pupil's assessment of teaching and of him/herself as learner-relevant items in the teacher's creation of effective learning environment. Croatian Journal of Education: Hrvatski časopis za odgoj i obrazovanje, 18(Sp. Ed. 1), 213-230. https://doi.org/10.15516/cje.v18i0.2219

Valenčič Zuljan M., \& Kalin J. (2020). Učne metode in razvoj učiteljeve metodične competence [Teaching methods and development of teacher methodological competence]. Ljubljana: Pedagoška fakulteta.

Valenčič Zuljan, M. (2002). Kognitivno-konstruktivistični model pouka in nadarjeni učenci [Cognitive-constructivist model of teaching and gifted students]. Pedagoška obzorja, 17(3-4), 3-12.

Valenčič Zuljan, M. (2007). Students' conceptions of knowledge, the role of the teacher and learner as important factors in a didactic school reform. Educational Studies, 33(1), 29-40. https://doi.org/10.1080/03055690600948166

Valenčič Zuljan, M. (2018). Factors of teachers' professional development. In N. Tatković, F. Šuran \& M. Diković (Eds.), Reaching horizons in contemporary education (pp. 9-31). Pula: Juraj Dobrila University of Pula, Faculty of Educational Sciences.

van der Lans, R. M., van de Grift, W. J., \& van Veen, K. (2017). Individual differences in teacher development: an exploration of the applicability of a stage model to assess individual teachers. Learning and Individual Differences, 58, 46-55. https:// doi.org/10.1016/j.lindif.2017.07.007

Vogrinc, J., \& Zuljan, M. V. (2009). Action research in schools-an important factor in teachers' professional development. Educational studies, 35(1), 53-63. https://doi.org/10.1080/03055690802470399

Vosniadou, S., loannides, C., Dimitrakopoulou, A., \& Papademetriou, E. (2001). Designing learning environments to promote conceptual change in science. Learning and instruction, 11(4-5), 381-419. https://doi.org/10.1016/S09594752(00)00038-4

Vujičić, L., Pejić Papak, P., \& Valenčić-Zuljan, M. (2020). Okruženje za učenje i kultura ustanove [Learning environment and culture institutions], Rijeka: Sveučilište u Rijeci, Učiteljski fakultet.

Wilen, W., Hutchison, J., \& Ishler, M. (2008). Dynamics of effective secondary teaching. Boston: Pearson.

Wolters, F. D. K. (1989). A PATT study among 10 to 12-year old students in the Netherlands. Journal of Technology Education, 1(1). Retrieved from https://vtechworks.lib.vt.edu/bitstream/handle/10919/8403/falco.pdf?sequence=1

Yager, R. E. (1991). The constructivist learning model: towards real reform in science education. The Science Teacher, 58(6), $52-57$. 